\title{
PENERAPAN MODEL PEMBELAJARAN ACTIVE LEARNING DENGAN MENGGUNAKAN MEDIA FLIP CHART UNTUK MENINGKATKAN PEMAHAMAN KONSEP PESERTA DIDIK KELAS XI IPA SMA NEGERI 1 TANJUNG BUNGA PADA MATERI SISTEM ORGAN
}

\author{
Adrianus Motong Liwun', Dwi Candra Setiawan ${ }^{2}$ \\ Pendidikan Biologi, Program Studi Pendidikan Biologi IKIP Budi Utomo, Malang \\ e-mail: dwicandra14@gmail.com
}

\begin{abstract}
Learning should be centered on the students centered this is in accordance with the demands of Education Unit Level Curriculum (KTSP). Learning in schools today is still conventional, which is teacher centered so that less reflects a meaningful learning for learners. Implementation of active learning model using flip chart media is expected to improve understanding of students' concept of class XI IPA SMA Negeri 1 Tanjung Bunga on organ system material. This research is a Classroom Action Research (PTK) consisting of two cycles. Population in this research is all student of SMA Negeri 1 Tanjung Bunga with sample is student of class XI IPA SMA Negeri 1 Tanjung Bunga. Improved understanding of learners' concepts can be measured using tests. The success of active learning model using flip chart media is seen through comparison between cycle I with cycle II. Based on the result of cycle I with cycle II, the percentage of concept improvement is $1.06 \%$, the result can be obtained through division of the second cycle gain divided by the acquisition of cycle I (80.95\%: 76.19\%). From these results it can be concluded that by applying the learning model of active learning by using the medi flip chart can improve understanding of the concept of learners.
\end{abstract}

Keywords: Active Learning, Flip Chart, understanding of concepts

\section{PENDAHULUAN}

Pendidikan merupakan faktor yang menjadi penentu dari kemajuan suatu bangsa. Semakin baik mutu pendidikan yang ditetapkan oleh suatu negara maka semakin besar kemajuan yang akan diperoleh negara tersebut. Sebaliknya, semakin rendah perhatian yang diberikan kepada mutu pendidikan, maka semakin kecil kemajuan yang diharapkan. Pendidikan adalah usaha atau upaya sadar yang dilakukan oleh pendidik agar peserta didik mampu mencapai tujuan tertentu (Menurut Soedjadi, 2000:6). Dalam proses pembelajaran, peserta didikdibantu untuk mengembangkan potensi intelektual yang dimilikinya. Peserta didik tidak boleh lagi dianggap sebagai subyek pembelajaran semata, tetapi harus berperan serta aktif dan dijadikan mitra dalam proses pembelajaran. Dengan demikian peserta didik bertindak sebagai agen pembelajar yang aktif, sementara guru bertindak sebagai fasilitator dan mediator yang kreatif (Rosyada: 2006).

Tujuan pembelajaran bukanhanya sekedar memahami konsep dan prinsip, tetapi juga membentuk peserta didik yang memiliki kemampuan yang dalam mengaplikasikan konsep dan prinsip yang telah dipahami tersebut dalam perbuatan dan tindakan sehari-hari. BSNP (2006) menjelaskan bahwa tujuan pelakasanaan pembelajaran biologi mampu mengembangkan kemampuan berpikir analitis, induktif dan 
deduktif dengan menggunakan konsep dan prinsip biologi yang telah dipelajari.

Berdasarkan hasil observasi yang dilakukan di SMA Negeri 1 Tanjung Bunga khususnya pada peserta didik kelas XI IPA, pemahaman konsep peserta didik terhadap materi masih kurang dikarenakan model pembelajaran yang digunakan oleh guru adalah direct learning yang mana pembelajaran masih berpusat pada guru sehingga peserta didik merasa bosan dan materi yang dijelaskanpun akhirnya tidak diterima dengan sepenuhnya. Minimnya pemahan konsep pada peserta didik kelas XI IPA SMA Negeri 1 Tanjung Bunga juga dipengaruhi oleh pemanfaatan media pembelajaran yang belum efektif.

Permasalahan-permasalahan tersebut diatas, dapat diatasi jika guru/pendidik secara cermat dalam memilih media dan model pembalajaran yang tepat. Salah satu model pembelajaran yang tepat adalah model pembelajaran active learning. Pembelajaran aktif (active learning) adalah suatu pembelajaran yang mengajak peserta didik untuk belajar secara aktif. Ketika peserta didik belajar dengan aktif, berarti mereka yang mendominasi aktifitas pembelajaran. Zaini (2008:16) menjelaskan bahwa secara aktif peserta didik menggunakan otak mereka untuk menemukan ide pokok dari materi pembelajaran, memecahkan persoalan serta mengaplikasikan apa yang diperoleh ke dalam suatu persoalan yang ada dalam kehidupan nyata.

Keaktifan peserta didik tersebut mencakup keaktifan dalam mendengarkan, mencatat inti materi, menyimak dan mengkonsep ulang atau merefleksi setiap materi yang sedang disajikan dan dibahas dalam proses pembelajaran dikelas. Dengan peran aktifpeserta didik pada proses interaksi pembelajaran di dalam tim (berupa kegiatan eksplorasi dan peer teaching) dan proses interaksi pembelajaran antar tim (team teching), diharapkan peserta didik mampu mengkonstruksi pengetahuannya sesuai dengan alur pikirannya sendiri dan selalu siap setiap saat untuk mempresentasikan ulang subtansi materi yang diperolehnya tersebut dengan kata-katanya sendiri.

Peningkatan pemahaman konsep peserta didik sangat terbantu bila dipadukan dengan media pembelajaran. Pada penelitian ini, peneliti menggunakan media flip chart sebagai salah satu media visual yang mempunyai fungsi memberikan informasi secara simbolis, memperjelas dan mempermudah peserta didik dalam menangkap data kuantitatif yang rumit dan juga media ini dapat menggambarkan pertumbuhan atau perkembangan suatu peristiwa atau objek dengan jelas sehingga peserta didik bisa lebih sistematis dalam mempelajari suatu peristiwa atau ilmu (Sumantri, 2005: 64). Selain itu Flip chart merupakan media cetak yang sederhana dan cukup efektif dari sisi pemanfaatan waktu untuk menyampaikan materi. Sederhana dilihat dari proses pembuatannya dan penggunaannya yang relatif mudah. Pemanfaatan media flip chart dalam pembelajaran adalah salah satu cara guru dalam efisiensi waktu terutama untuk menulis di papan tulis, karena penyampaian informasi ini dapat berupa gambar, huruf, diagram dan angka-angka.

Berangkat dari permasalahanpermasalahan tersebut diatas, peneliti melakukan penelitian dengan judul penelitian "Penerapan Model Pembelajaran Active Learning Dengan Menggunakan Media Flip Chart Untuk Meningkatkan Pemahaman Konsep Peserta Didik Kelas XISMAN 1 Tanjung Bunga Pada Materi Sistem Organ”. 
METODE PENELITIAN

Penelitian ini menggunakan teknik analisis deskriptif yaitu suatu metode penelitian yang bersifat menggambarkan kenyataan atau fakta sesuai data yang diperoleh dengan tujuan untuk mengetahui hasil belajar yang dicapai peserta didik dan juga untuk mengetahui respon peserta didik terhadap kegiatan pembelajaran serta aktivitas peserta didik selama proses pembelajaran. Pada penelitian ini, aspek yang diteliti adalah penilaian kognitif peserta didik, yaitu pemahaman konsep peserta didik terhadap materi sistem organ.

Penelitian ini adalah penelitian tindakan kelas (PTK) yang dirancang dua siklus, dengan setiap siklus terdiri dari empat tahap yaitu 1) tahap perencanaan, 2) tahap pelaksanaan, 3) tahap observasi dan 4) tahap refleksi (Arikunto, 2006). Dengan subyek penelitian adalah peserta didik kelas XI IPA SMAN 1 Tanjung Bunga yang berjumlah 21 orang.

Instrumen yang digunakan untuk mengumpulkan data pada penelitian ini adalah berupa 1) Instrumen pembelajaran berupa silabus dan RPP 2) Instrumen penilaian berupa lembar observasi, angket, catatan lapangan dan LKS.

Teknik analisis data untuk mengukur kemampuan pemahaman konsep peserta didik diukur melalui aspek kognitif dengan menggunakan rumus sebagai berikut:

$$
\text { Skor tes }=\frac{\sum \text { skor yang dicapai }}{\sum \text { skor maksimal }} \times 100
$$

Untuk prosentase ketuntasan belajar klasikal mealui rumus berikut:

$$
P=\frac{\sum j m l \text { siswa mendapat nilap } 70}{\text { Ejumlah seluruh siswa }} \times 100 \%
$$

\section{HASIL DAN PEMBAHASAN}

Berdasarkan paparan dan analisis data yang diperoleh maka dapat diketahui bahwa penerapan model pembelajaran active learning dengan menggunakan media flip chart dapat meningkatkan pemahaman konsep peserta didik kelas XI IPA SMA Negeri 1 Tanjung Bunga pada materi sistem organ,yaitu dari siklus I 76,19\% meningkat menjadi $80,95 \%$ pada siklus II.

Peningkatan pemahaman konsep peserta didik dalam penelitian ini dikarenakan active learning merupakan salah satu model pembelajaran kooperatif. Pembelajaran koopertif merupakan suatu model pembelajaran yang menekankan agar peserta didik belajar dan bekerjasama dalam kelompok-kelompok kecil secara kolaboratif yang beranggotakan 4-6 orang dengan struktur kelompok heterogen (Slavin, 1995) Lebih jelas lagi Harjono (2013) menjelaskan adanya peningkatan pemahaman konsep peserta didik terhadap materi alat optik dan active learning juga memungkinkan aktifitas berbicara dan mendengar, menulis, membaca dan refleksi yang menggiring ke arah pemaknaan mengenai isi pelajaran.

Pendapat diatas sesuai dengan penelitian dari Laws, dkk., (1999) tentang active learning, dimana pemahaman konsep meningkat setelah diterapkan model active learning. Lebih lanjut lagi Laws, dkk (1999) menjelaskan tentang metode kooperatif, juga menunjukkan peserta didik akan saling berdiskusi untuk memperoleh pemahaman yang lebih baik daripada dengan pembelajaran konvensional.

Peningkatan pemahaman konsep peserta didik membutuhkan model pembelajaran dan media pembelajaran yang sesuai. Penerapan model pembelajaran active learning dengan media flip chart sangatlah membantu dalam meningkatkan pemahaman konsep peserta didik kelas XI 
IPA SMA Negeri 1 Tanjung Bunga pada materi sistem organ, dapat diketahui dari perbandingan siklus I dengan siklus II, yaitu peningkatan sebesar $1,06 \%$. Penggunaan media flip chart sangatlah membantu dalam meningkatkan pemahaman konsep peserta didik kelas XI IPA SMA Negeri 1 Tanjung Bunga pada materi sistem organ. Hal ini dikarenakan media flip chart merupakan salah satu media grafis berupa gambar, cetak dan diam dalam bentuk buku bagan atau chart. Media grafis sebagai media pengajaran yang dapat mengkombinasikan fakta-fakta, gagasan-gagasan secara jelas dan kuat sehingga dengan hal ini dapat memampukan peserta didik untuk memahami konsep materi pembelajaran Sudjana (2009). Media flip chart mampu memberdayakan pemahaman konsep siswa, terutama membantu memahami pada materi yang bersifat abstrak. Dengan adanya media flip chart yang gambar atau grafis sederhana akan memudahkan siswa memahami materi abstrak tersebut. Hal ini sesuai dengan pendapat Hasanah (2015) yang menjelaskan media flip chart sebagai media pembelajaran berfungsi memperjelas dalam penyajian materi terutama pada mata pelajaran IPS yang umumnya bersifat abstrak sehingga dengan adanya media ini memberikan pemahaman yang tepat tentang materi pembelajaran yang telah disampaiakan

Media flip chart diyakini sangat membantu peserta didik dalam memahami materi secara mendalam, karena adanya media flip chart yang berisikan gambargambar sehingga peserta didik memperoleh pengalaman langsung, warna-warna yang cerah bisa untuk daya tarik (Hadzik, 1996).

\section{SIMPULAN DAN SARAN}

Berdasarkan hasil penelitian dapat disimpulkan bahwa penerapan pembelajaran active learning dengan menggunakan media
Dalam proses belajar mengajar dengan menggunakan media flip chart memberikan kesempatan dan menuntut peserta didik terlibat aktif di dalam mencapai tujuan pembelajaran dengan memberikan bantuan secara bertahap sehingga peserta didik dapat memecahkan masalah yang ada (Hadzik: 1996). Media pembelajaran flip chart juga dapat meningkatkan hasil belajar peserta didik serta membuat peserta didik lebih semangat untuk mengikuti proses pembelajaran, memudahkan peserta didik dalam memahami materi pelajaran dan mampu meningkatkan hasil belajar peserta didik dalam pembelajaran IPS terpadu (Roja'I: 2016).

Sistem organ merupakan salah satu materi biologi yang dipelajari peserta didik kelas XI IPA SMA Negeri 1 Tanjung Bunga semester genap pada kurikulum KTSP 2006. Dalam mejelaskan materi sistem organ, guru menjelaskan melalui media flip chart sehingga peserta didik dapat langsung melihat bentuk dari organ-organ tersebut. Media flip chart yang digunakan cukup menarik sehingga dapat menarik perhatian peserta didik untuk memahami materi yang dijelaskan. Flip chart sebagai salah satu media visual mempunyai fungsi yaitu memberi informasi secara simbolis, memperjelas dan mempermudah peserta didik dalam menangkap data yang kuantitatif yang rumit dan juga media ini dapat menggambarkan pertumbuhan atau perkembangan suatu peristiwa atau objek dengan jelas sehingga peserta didik bisa lebih sistematis dalam mempelajari suatu peristiwa atau ilmu (Sumantri 2005).

flip chart dapat meningkatkan pemahaman konsep peserta didik. Saran yang dapat diberikan adalah untuk penelitian selanjutnya disarankan untuk dilakukan penelitian jenis 
Vol. 3, No. 1 : Hal 1-5

Februari 2018

quasi eksperimen agar diperoleh hasil yang lebih baik.

\section{RUJUKAN}

Arikunto, S. 2006. Prosedur Penelitian: Suatu Pendekatan Praktik. Jakarta Rineka Cipta.

BSNP. (2006). Panduan Pengembangan Silabus Kurikulum Tingkat Satuan Pendidikan(KTSP)Sekolah Dasar (SD) / Madrasah Ibtidaiyah (MI). Jakarta: CV. Laksana Mandiri.

Depdiknas. (2007). Pedoman Pembelajaran Bidang Pembelajaran Fisika/Motorik di TK (Buku 4). Jakarta: Direktorat Pembinaan TK SD.

Hadzik, M. 1996. Penerapan Media Flip Chart untuk meningkatkan pemahaman siswa MA Hasyim Asy'ari. Surabaya. Online .

Harjono, A. C. 2013. Penerapan Model Active Learning Berbasis Kooperatif untuk meningkatkan pemahaman konsep dan kinerja siswa. FMIPA Universitas Negeri Semarang. Online.

Hasanah, U. 2015.Pengaruh Penggunaan Media Flip Chart terhadap Hasil Belajar IPS Kelas VIII MTS Negeri 3 Jakarta.Online.

Laws, P., D. Sokoloff, and R. Thornton. 1999. Promoting Active Learning
Using the Results of Physics

Education Research. Uni Serve Science News- Volume 13.

Roja'I, M. (2016).Pengaruh Penggunaan Media Flip Chart Terhadap Hasil Belajar IPS Terpadu Siswa Kelas VII Pada Konsep Kegiatan Pokok Ekonomi di SMP Islam Terpadu Rahmniyah Cilodong. Jakarta.

Slavin, R.E. (1995). Cooperative Learning. Bandung: Nusa Media

Soedjadi, R. 2000. Kiat Pendidikan Matematika Di Indonesia. Jakarta: Direktorat Pendidikan Tinggi DEPDIKNAS.

Sudjana, N. (2009) Penilaian Hasil Belajar Mengajar. Bandung: PT Remaja Rosdakarya.

Sumantri, MS. (2005). Model Pengembangan Keterampilan Motori Anak Usia Dini. Jakarta: Depdiknas-Dirje PT.

Zaini, Hisyam. 2008. Strategi Pembelajaran Kooperatif. Jakarta: Rineka Cipta. 